\title{
ASPECTS OF ECOLOGICAL MARGINALIZATION AND ALTERNATIVE LOCAL RESPONSES IN RURAL GREECE
}

\author{
Eugenia A. Petropoulou \\ Department of Sociology \\ School of Social, Economic and Political Science \\ University of Crete \\ University Campus, 74100, Gallos Rethymno, Greece \\ e-mail: petrope@uoc.gr
}

\begin{abstract}
The conditions under which people live in rural areas, the ways in which resources are utilized and the prospects for conservation in the future are all in part influenced by the fundamental characteristics of national governments, European Union policies for economic and sectoral development, as well as processes such as globalization. Using an ecological marginalization perspective, this paper illustrates the consequences of proliferating intensive agriculture 'alliances' among European Union policies, the Greek state, and Greek domestic producers. Since many natural resources - soil, water, biodiversity are already entrenched in industrial agricultural production systems, the author extrapolates from the patterns of production that make use of these natural resources to bolster the argument that Greek state policies, the timing of the country's accession to the European Community in 1981, and local land use practices will particularly affect the potential consequences of future agricultural development. Even though the impacts of intensive agriculture vary by region and some rural areas have benefited from this development, the analysis suggests that rural people, communities and citizens of peri-urban territories all bear the costs of the industrial agriculture production system both in terms of social, health and environmental impacts. A core reason, this paper argues, is that the 'alliances' of intensive industrial agriculture are reinforcing processes and structures that increase pressure on the ecological integrity of rural areas leading to environmental degradation and the marginalization-abandonment of agriculture. Finally, the paper traces the cases of Alternative Agro-Food Networks (AAFNs) in Greece that promote socio-economic sustainability and health to local producers and consumers as an alternative to the current intensive agro-industrial food system which supports ecological marginalization.
\end{abstract}

Keywords: Alternative Agro-Food Networks, ecological marginalization, European Union, Greece, rural areas

\section{INTRODUCTION ${ }^{1}$}

The conditions under which people live in rural areas, the ways in which resources are utilized and the prospects for conservation in the future are all in part influenced by

1 I would like to thank all the blind reviewers who have contributed to this paper with their valuable comments, criticisms and questions about earlier drafts. 
the fundamental characteristics of national governments, EU policies for economic and sectoral development as well as processes such as globalization (Primdahl, 2010). These forces at the global (international - EU - national) level are translated at the -lower local level of the agent of ecological marginalization and the inevitable repercussions for sustainable development and democracy particularly in times of crisis (Kousis, 1998; Lekakis and Kousis, 2013).

The literature on ecological marginalization in the Mediterranean or similar environments deals with the transformation of local natural resources by powerful economic actors such as the State, EU and global institutions, and the gradual or immediate disorganization of the ecosystem via withdrawals and additions to the rural environment ${ }^{2}$. In response, citizens or rural people given their organizational resources and interpretive frames, as well as political and economic opportunity structures, choose not to react or react by mobilizing at the grassroots level (Kousis, 1997, 1998), or alternatively prefer to participate in Alternative Agro-Food Networks ${ }^{3}$ (AAFNs) as an indirect means to contention in order to protect their ecological base, health and economy particularly in times of crisis (D'Alisa et al., 2013; Forno, 2014).

2 The idea of withdrawals and additions to the ecosystem comes from the "treadmill of production theory" which was coined by Allan Schnaiberg (1980) in his book The Environment: From Surplus to Scarcity. The basis of this theory is that humans are dependent upon a constant flow of energy from nature and that each of us is in a constant state of interaction with the world around us. We are constantly taking in the natural world through food, water, air, etc. and likewise constantly releasing it back into the ecosystem (e.g. via feces, urine, exhaled breath, etc.). In this process humans create withdrawals, which are the extractions of raw materials from nature, and similarly create additions, which are the waste and byproducts created through the production of human consumed goods. Many additions like nuclear waste, toxic chemicals, and greenhouse gasses create profound ecological disruptions.

3 An AAFN is "a collective body / unit that organizes collective or non-collective actions-events carrying out alternatives to dominant socio-economic and cultural practices with visible beneficiaries". Their (AAFNs) actions are engaged in the public sphere and are not operated / fully supported by mainstream economic and political organizations (i.e. corporate, state, or EU related agencies). In addition, their actions are characterized by a cooperative framework aiming to provide people alternative ways of consumption and food security against the current agro-industrial food system. Central characteristics include the following: social cooperation or partnership among producers, among consumers, and between those two groups, potentially linking distant localities; money as an intermediary for such proximate relations between producers-consumers; producers' economic independence from the agro-industrial system as a basis for production methods which may be more benign in the social, economic and / or environmental sense; active citizenship valorizing food products and production as a political-ethical commitment; the public good, e.g. social justice or solidarity between producers-consumers, environmental improvement via alternative production methods, regional development via local economic benefits, local heritage, etc.; socioterritorial identities based on those aims; and food embedded in trust, community, proximate relations and place-based production. Through those extra-economic characteristics, alternative networks promote alternative products and production processes, e.g. product quality, special taste, freshness, special processing, etc.; territorial origins, e.g. local producers, local reputations, heritage, etc.; and ecological advantages, e.g. less-intensive cultivation processes, non-industrial local inputs, agro-ecological methods, organic / bio certification, biodiversity conservation, etc. The methodological tools adopted for Greek AAFNs are partially derived from an EU funded project (LIVEWHAT, URL: http://www.livewhat.unige.ch). See also Petropoulou, 2016. 
Following A. Schnaiberg (1980), it is possible to succinctly present the twists and turns of the current economic model that leads to ecological marginalization (Kousis, 1998). According to this American sociologist, over the last 30 years industrialized society has been experiencing a new model of economic growth whose core aim was to foster a culture of freedom based on technological innovations, resource extraction and entrepreneurship (i.e. open ecology sources, intensive agriculture etc.). Yet according to Castells et al. (2012), industrialized society has somehow favored the waves of deregulation, privatization and liberalization, which have been the main objectives of the neo-liberal agenda since the '80s. In 2008 this economic model entered into a crisis. Ecological economists underlined that the crisis was caused not only by abuse in the financial economy, i.e. credits, collaterals, futures and derivatives trading, and malfunctions of the real economy, i.e. factories, farms and services, but also by the plunder of what they defined as the real-real economy - i.e. eco-system services, fossil fuels, natural gas deposits and sink capacity (Kallis et al., 2009). Complementing the outlined diagnosis, de-growth scholars maintained that it was not only a crisis of global capitalism, but also a crisis of extractivist economy, the biophysical support of the former, an ecological crisis. In brief: an ecological crisis articulated around the twin economic imperatives of growth and development (D'Alisa et al., 2014). If this is true, how then has the collapse of the current socio-economic system been avoided (or postponed)? Ecological marginalization processes - thanks to powerful 'alliances' between economic actors, international organizations (the EU), the state and producers - employ various forms of control capacity to influence the state in regulating access to ecosystems, based on a mix of money and subsidy policies. These types of policies, in actual fact, share a core objective: the re-launch of growth. Moreover, such policies have only been helpful for a few but disastrous for the majority of the rural population that has been forced to bear the brunt of them. As a consequence, alternative agro-food networks and initiatives have been appearing lately (Forno, 2013; Forno and Graziano, 2014; Grasseni et al., 2015). The Greek state, as well as international organizations such as the EU, is directly or indirectly involved in the decisions and policies that lead to or intensify ecological marginalization. Even today, what is left of the modern welfare state is experiencing a conflict between its function as a promoter of economic growth by ensuring the conditions for profitable capital accumulation, and its function as a social legitimator by maintaining social harmony (Sotiropoulos, 2014). The main path to economic growth has been through the exploitation of environmental resources by farmers and / or local users with state assistance, whereas social harmony implies state actions aiming to preserve the capacity of ecosystems for the benefit of the citizens.

The aim of this paper is to illustrate the process of ecological marginalization in rural Greece, the environmental and socio-economic consequences of these processes and, where applicable, local responses to this. The first section of the paper examines the process of ecological marginalization in rural areas of Greece, within the limitations of available national and international material and literature. It presents the driving forces of ecological marginalization in Greece strongly linked to EU / State policies, 
globalization processes (e.g. trade liberalization, global competition) and urbanization in peri-urban areas (Primdahl, 2010; Vlachos, 2011). The second section traces the cases of Alternative Agro-Food Networks (AAFNs). These networks are indicative of citizens' attempts to change the economic system, increasingly perceived as unfair and ecologically disruptive, by building an alternative in the cracks of the former, based on greater mutual solidarity between individuals and more sustainable connections with the environment (D’ Alisa et al., 2015; Petropoulou, 2016).

\section{ECOLOGICAL MARGINALIZATION: EU AND THE GREEK STATE}

During the last three decades, an increasing number of Greek governments have come to recognize the futility of earlier strategies which emphasized urban-based industrialization at the expense of agriculture and the rural sector (Vlachos, 2011; Symeonakis et al., 2012). In addition, the rural sector has been increasingly experiencing the depletion of non-renewable natural resources and the negative impacts of environmental externalities on local ecosystems and populations under the auspices of the EU and the global economic system.

The European Community's agricultural policy of the post-war period took away local control of agriculture and passed it to state groups and institutions. In Greece, as elsewhere, this included mechanization, the development of irrigation systems, new methods of cultivation or systematic stock breeding, the use of chemical fertilizers, herbicides or insecticides and improved varieties of seed or animal species, etc. For example, the key factor in raising yields in Greek agriculture has been the increase in the use of chemical-inorganic fertilizers which is high in the plains. A result of this rapid technological progress was the immense improvement of agricultural labor productivity and production growth (Liodakis, 1997).

In 1981, after the country's accession to the European Economic Community (EEC), the Socialist party in Greece came to power and committed to transforming the national economy and society, to redress the inherited social and spatial inequalities between regions, and in particular, to raise the quality of life in the rural farming areas where almost half of the population lives (ESYE: 1961, 1971, 1981, 1991, 2001, and 2011 population censuses). It immediately embarked upon a dual rural development strategy under the commands of the Common Agricultural Policy (CAP) $)^{4}$, involving the intensification of agricultural production and the support of agricultural incomes following European overproduction trends (Pezaros, 2012). Throughout the 1980s, considerable progress was made towards improving agriculture and general living conditions particularly in lowland regions where agricultural industrialization took place. The measures adopted

4 CAP (Common Agricultural Policy) is the agricultural policy of the European Union. It is one of the EU's oldest policies and was strongly rooted to the European Integration project and has been reformed on many occasions, during the crisis years of 1970 and 1980 up until the 2013-2020 reform. 
included the provision of health and education services, improved irrigation facilities, transport and agricultural marketing facilities and funds-credit services (Maraveyias and Mermigkas, 2002). Up to the 1990s European agriculture and consequently Greek agriculture had been characterized as a success story validating its initial objectives for increase of production and raising farmers' quality of life (Louloudis and Beopoulos, 2002). In terms of ecological marginalization, agricultural intensification in Greece became subjective to the quantitative exploitation of natural resources in rural areas after the post-war period by the state, EU, global institutions and urbanization expansion. The transformation of Greek rural ecosystems altered their functional (i.e. natural resources) and organizational (i.e. local population) integrity. In other words, the agricultural industrialization of Greek agriculture involved withdrawals $s^{5}$ from and at the same time additions $^{6}$ to the local rural ecosystems. Since the 1960s and specifically after the 1980s, the Greek state gradually promoted the intensification and industrialization of agricultural production by taking the control of agriculture away from the local people. Seed resources were passed to state groups (Papadopoulos, 1999), while external control under cash cropping activities (i.e. monoculture, overgrazing etc.) has continued degrading the rural environment in the form of soil erosion processes, water contamination, landscape degradation etc., whereas each step of agricultural intensification was determined by the ever more centralized government and EU interests (Lekakis and Kousis, 1994).

In addition, the drive for continuous agricultural intensification and capital accumulation supplements three important characteristics of the modern treadmill model in rural areas: the growth of production refers to the tendency of farmers to adjust to the competitive pressure of technological modernization (Liodakis, 1997), the production process is shifted away from localized subsistence towards national and international markets, and the institutional apparatus generates additional demands for increased ecosystem utilization in order to strengthen and support an even greater capitalization of production (Kousis, 1998:91). Global organizations, such as the World Trade Organization (WTO), are promoting growth even more intensively than before. The formation of the WTO immediately eliminated the transnational trade barriers and increased the transnational flow of goods and capital dramatically, resulting in accelerated industrial production via access to more resources and greater market penetration. Large-scale free trade results in the economic and political disempowerment of local communities, the rapid loss of natural resources and the irreversible degradation of ecosystems (Liodakis, 1997). These environmental offences lead not only to negative ecosystem impacts but to negative socio-economic, political and health effects in terms of damages to the local population (Kousis, 1998).

5 Withdrawals from the ecosystem means, e.g. the control of seed resources, whose raw materials come from less developed countries, from economic actors or institutions that are based in industrialized countries. Also, biotechnology and market power has increased the control of food production and distribution by large multinational corporations.

6 Additions to the ecosystem are where seed resources are substituted by hybrids which demand large amounts of water and chemicals with negative impacts on natural resources (i.e. water and soil contamination) and health impacts to rural populations (Petropoulou and Petousi, 2016). 
Finally, the institutional success of European and Greek agriculture is still strongly dependent on a competitive world economy even today. Therefore, the severe crisis currently facing agriculture in Greece reveals itself by a growing instability of world markets, increasing competition, serious fiscal stress at the EU and country level, the international dissemination of the model of technological innovation and intervention in agriculture (intensive, industrialized and energy-consuming agriculture) as well as the failure to anticipate or substantially contain environmental problems (Liodakis, 1997; Lekakis and Kousis, 2013; Petropoulou, 2014).

\subsection{Impacts of intensive agriculture: withdrawals and additions to the rural ecosystem}

The environmental impacts of intensive or industrial agriculture has been globalized through the so-called Green Revolution, developed by advanced Western countries around the early 1960s, to be utilized in less developed countries by resolving intense food shortages in order to avoid social explosions (Parayil, 1992). In Greece, the use of seeds of improved high-yielding crop varieties (mainly cereals) with intensive mechanization, fertilizer and irrigation led to the extinction of local seed varieties and thus to a decrease in biodiversity, signaling an enduring ecosystem withdrawal. The greater demand for water leads to a decrease in valuable water resources with wider ecosystem implications. Monoculture and intensive agricultural techniques lead to soil erosion. The more apparent impacts are due to the use of chemical fertilizers and pesticides (Beopoulos and Skuras, 1997). In mountainous and semi-mountainous zones weed control is carried out by a generalized use of herbicides while new varieties, at the expense of traditional ones, are more demanding in terms of plant protection thus endangering the environment even further. Consequently, the environmental impacts take various forms of withdrawals and additions regarding offences to the rural ecosystem, e.g. monoculture, landscape impacts and overgrazing impacts as well as water and land contamination, soil erosion and land abandonment etc., seen analytically below (Rene, 2011).

The following types of ecosystem offences stem mainly from the "subsidized" period of the 1980s, which was abruptly terminated in 2008 by the ongoing economic crisis. Agricultural subsidies in the 1980s (70\% derived from the EU and 30\% from state subsidies) and onward seemed to be an important "vehicle" for food security and increases in production (Bourdaras, 2007). New high yield varieties and monoculture led to intensification of production, which consequently became the motive of increasing farming incomes since economic support was strongly linked to the magnitude of production with the help of subsidies. Primary producers ceased to associate their income with land quality, and this appears to be one important reason, among others, for the intensification of farming and grazing practices (Beopoulos and Vlachos, 2004).

Irrigation is also another indication of intensive agriculture promoted in Greece. Greek farmers irrigating their land use improved seeds, fertilizers and pesticides in order to increase yields and achieve regularity and quality of the produce due to the uneven distribution of rain. Irrigation was and still is associated with vegetable cultivation and fruit plantations. But the most significant irrigated lands are reserved for industrial 
arable crops such as maize, sugar beet, perennial varieties of clover and mostly cotton (Beopoulos and Skuras, 1997). The increasing needs for irrigation water is associated with the demands of the new hybrid varieties resulting in the squandering of this natural resource. The over-extraction of water occurring in coastal areas has caused sea water to infiltrate fresh water, making ground waters brackish.

Moreover, the expansion of cultivated areas and irrigation could also be considered an indicator of the pressure exerted on wetlands by agriculture. As farmers strive to exploit the agricultural potential of the usually flat and fertile zones around the wetlands, they get closer to the core of these areas. What is more, by 'withdrawing' or pumping water vital for the survival and conservation of the wetlands, they drive these highly valuable natural areas to fragmentation and drainage (Galanis and Karagiannis, 2000; Petsikou, 2001). Besides, the transfer-'additions' of potentially polluting substances (i.e. fertilizers and pesticides) by irrigation water creates problems in the wetlands, thus indirectly endangering wildlife species.

Intensification affects production processes but also the various production systems and farms such as farm enlargement and specialization (i.e. monoculture). Land consolidation and redistribution in the semi-mountainous zones in Greece on the one hand acted as a kingpin for improving agricultural productivity, but at the same time led to the uprooting of natural farm hedges and felt streams with pits and debris (Murray and Skuras, 1990). In some cases land redistribution was applied in areas low in agricultural yet high in ecological value. Consequently, in areas that had a tendency towards soil erosion, this phenomenon was exacerbated. Agricultural land has largely lost its value as a natural habitat of particular plant and animal species, since the remains of all natural vegetation, as well as hedges separating farmsteads, had disappeared. Finally, land consolidation destroyed certain elements of traditional rural landscapes and manifested itself in the decline of traditional mixed farming systems (Blondel, 2006).

The traditional practice of fallow land has diminished in mountainous and semi-mountainous areas as well as rotational practices (Berkes, 2008). New farming practices adjusted to the short-life cycle of high yield varieties and limited the importance of certain plants associated with Mediterranean crop rotations (nitrogen-fixing legumes) (Petropoulou, 2007). Along these lines the rotation of cotton cultivation, a highly subsidized and demanding plant in terms of irrigation, has vanished resulting in a total drop of production in the early 2000s.

Furthermore, soil erosion is specifically linked to certain aspects of agricultural intensification such as specialization of the production systems, increase of plot size, etc. A study focusing on the prefecture of Messinia revealed that land abandonment of vines in the mid-80s was supported by EU policies that favored and subsidized new high yield varieties (Millington, 1990). Land abandonment increases the risk of summer fires and destroys the traditional rural landscape of grape vines and olive groves. On the other hand, abandoned lands experience a re-generation of maquis, a pseudo-steppe phrygane that signals the early stages of land degradation that leads to soil erosion. Forest fires favor soil erosion while constituting the most serious threat for Greek forests. 
Another loss of the adaptive capability of land users to cope with changing environmental conditions can be seen in the treatment of unwanted scrubs and organic waste of the farmland. Farmers try to repel it by using fire while at the same time grazing intensity remains high. Such reaction promotes soil erosion and infertility (Kizos and Vlachos, 2012). In the presence of strong economic drivers in the form of actual agricultural support systems and in the absence of strong cultural traditions and institutions in many rural areas of Greece, the loss of traditional knowledge of land use practices is visibly documented by the decaying cultural landscape elements (terraces, stonewalls, buildings, etc.) (Petanidou et al., 2008).

Driven by changes in the agricultural policies and technologies and the production of the common agricultural policy market of the EU (especially the adoption of its subsidy system in the form of livestock subsidies per head), the current livestock system on the Greek islands (i.e. Lesvos) is motivated by agricultural subsidies (Beopoulos and Vlachos, 2004). Sheep farmers tend to increase the size of their herd to compensate for the loss of income per animal from the steady prices of milk they receive. Subsequently, they become more dependent on animal feed which is imported and they rely largely on subsidies. This appears to be a response to the marginal conditions since little else is available and the intensification of sheep husbandry, however radical, becomes the choice of increasing incomes, especially considering the rather supportive policy environment that links the size of the herd with the subsidy. In terms of livestock, the rising world-market prices for livestock feed and fodder and the ongoing economic crisis have brought forward a simple economic driver that either forces farmers to reduce flocks (abandonment is a less likely choice since with the current unemployment rate in Greece at more than 20\% no other occupations are available) or urges them to try to 'squeeze' more feed out of their grazing lands (Kizos and Vlachos, 2012).

\subsection{Socio-economic impacts}

The political repercussions of intensive-industrial agriculture are evident and multifaceted. Local control of agriculture has steadily been lost while the impoverishment of rural communities becomes a reality in all parts of the globe (Gomez-Baggethun et al., 2010). Industrial agriculture promoted by the EU and state policies, along with the joint forces of agricultural and chemical companies, has a distinct socio-economic impact on public health due to external chemical inputs. According to ILO's ranking (2011), agriculture is one of the three most hazardous sectors followed by mining and construction in both developing and industrialized countries. The popularity of pesticide use in Greece can be traced to the Green Revolution era (1960s-70s) that introduced the use of pesticides as a prerequisite input to obtaining high crop yields. Boosted by the available subsidies and loan schemes since the 1980s, Greek farmers sprayed their fields as much as 7 times per cropping season (Louloudis and Beopoulos, 2002).

Chemical dependence has become an acceptable norm to the extent that it is increasingly being adopted even by subsistence farmers engaged in some cash crop production in upland areas today. Again, according to ILO (2011), between 400,000 to 2,000,000 
farm workers are poisoned each year while women are mostly affected. The findings of epidemiologic and occupational studies done mostly in the West have found that toxins stored in women's bodies increasingly predispose them to various reproductive health disorders and malignancies including hormonal disruptions or interferences in the estrogen level that alter the normal menstrual cycle and cause pregnancy complications, miscarriages, stillbirths, birth defects, delayed pregnancy, reduced ability to breastfeed, endometriosis, and breast and ovarian cancers (Petropoulou and Petousi, 2016). Moreover, pesticide residues are passed on by mothers to babies through breastmilk. Inhabitants of rural farming areas show higher cancer rates, birth defects, nervous disorders and sterility due to exposure to pesticides and inorganic fertilizers (Andrersson and Lundqvist, 2014). For farmers and consumers of industrial agricultural products, the latest research findings point to new and more serious concerns than considered to date, i.e. increasing cancer rates, damage from pesticide use for all forms of life such as endocrine system effects in humans, etc. (Demos et al., 2010).

The unequal allocation of subsidies through clientelist networks in many parts of Greece mainly benefited larger farmers and as a consequence has eroded social trust and trust in institutions. The rationale of national, regional and local authorities was to "avoid 'losing' money" that could be paid to the local farmers. Initially, in the 1980s, subsidies were allocated through informal patron-client networks, which undermined the prospects for modernization of production and environmental sustainability (Lorent et al., 2009). Under this regime, subsidies were mainly seen as additional and "easy" income. They exacerbated economic and social inequalities in many parts of Greece and further eroded the trust between individuals and social groups and between social groups and formal local / regional institutions (Paraskevopoulos, 2007). Moreover, this way of allocating agricultural subsidies undermined the past social relations of trust, solidarity, and reciprocity among farmers in most rural Greek areas (Cosyns et al., 2014; Fisher, 2013).

The above tendency led to the neglect of the quality and long-term conservation of the land and to investments in the intensification of land-use practices mainly because primary producers would not connect their income to the long-term quality of land. Under these conditions, projects for "rationalization" and "modernization" of agricultural or livestock production and / or attempts to introduce viable policies, such as the extensification of grazing carried out under the CAP (Common Agricultural Policy) in the early 2000s, faced serious resistance (Briassoulis, 2004).

Many regions in Greece, mainly mountainous, saw a decline in population, which resulted in changing land use, abandonment of marginal lands as a result of such agricultural policies and practices with possible opportunities elsewhere (Caraveli, 2000), steadily marginalizing farming as an occupation. The marginalization of farming ${ }^{7}$ (Beaufoy et al., 1994) may lead to different strategies, or responses from farmers, such as change of land

7 The marginalization of farming is a process driven by a combination of social, economic, political and environmental factors, by which certain areas of farmland cease to be viable under an existing land use and socio-economic structure (Beaufoy et al., 1994). 
use, e.g. from crops to grassland or forests or buildings; reduced inputs, stocking densities, maintenance of infrastructure ('extensification'); restructuring of farming, farms being taken over by other farmers (enlargement); contraction of the farming system, intensification in places, abandonment elsewhere; or complete land abandonment. Area-specific intensification is based on mechanization but also on the availability of cheap immigrant labor during the past 20 years (Kizos and Vlachos, 2012).

Social driving forces enhance the decreasing attractiveness of farming as a livelihood compared to services, along with the increased importance of second holiday homes, and the quality of life offered in cities. Economic driving forces include the low profitability and productivity of farming, new transport infrastructure and especially roads, the rise of tourism as an economic activity in addition to the increasing importance of EU level agricultural policies which have rapidly altered many rural landscapes (Benoit and Comeau, 2005; Caraveli, 2000). On the other hand, the economic crisis seems to affect Greek rural areas, which may relate to the dependency of people on the land and its resources. In Greece people have returned to the countryside, exploiting olive yards for firewood which is seen from the cutting and pruning of trees (Lekakis and Kousis, 2013). Furthermore, the tourist-urban-industrial sprawl is evident mostly in peri-urban areas, along coasts and roads. Farmland in these areas is very expensive and this sprawl takes up high quality farmland, but also results in the fragmentation of the landscape. A common driving force behind these changes is housing pressures. Since Greek building legislation allows building outside settlements only on non-forested agricultural land of a size larger than $0.4 \mathrm{ha}$, farmland is not protected at all and the difference in land value makes all fields potential real estate plots. This is linked with the unattractiveness of agriculture as an economic activity in Greece today that results in aged owners and abandonment of farmland due to the poor economic performance of most cultivations today (especially low-input olive farming). Therefore, part-time farming with small and hobby farmers is spreading.

Land use and landscape changes along with the urbanization expansion lines on many Greek islands (Kizos et al., 2011) was related to olive plantations being removed (along with the terraces that supported them) for housing / manufacture / infrastructure uses. In the peri-urban area of greater Athens the construction of the new Greek airport, accompanied by a new road and rail connection to Athens (along with a new plan for town expansion that started in 1998 and concluded in 2008), have transformed the area and the landscape completely from a small town surrounded by vineyards and olives into an expanding urban center with a countryside for manufacture, industry and new recreation uses (e.g. turf football grounds; fields for wedding receptions, etc.). These socio-economic activities drastically altered the rural ecosystem causing irreversible landscape changes. This transformation in turn sets limits on the future value of the local resource-based economy such as changes or decline in property values. Thus, the low profitability of farming practiced in the above cases compared with other economic activities and the fact that urban space has grown rapidly, consuming most surrounding farm areas, signals the collapse of farming profitability (Kizos et al., 2011). At the same 
time, landscape features are being neglected or destroyed, often leading to the degradation of landscape and nature values (Benoit and Comeau, 2005; Martin, 2016).

\subsection{Alternative local responses}

Local responses to ecological marginalization do not always foster opposition. Since the global financial crisis of 2008, alternative to mainstream forms of economic and noneconomic activities of locally based groups which are 'indirectly' opposed to the industrialization and globalization of agriculture have emerged. Ecological marginalization therefore creates the necessary preconditions for any alternative structures and initiatives that may lead to environment-linked forms of sustainable production and consumption patterns. Therefore, Alternative Agro-Food Networks (AAFNs) may respond to environmental, social and economic needs that have been generated by recent world development practices while they point to a transfer of power away from the national state and capital operating at a national scale, towards smaller communities (Castells et al., 2012).

Factors that may lead to a reaction to ecological marginalization include economic opportunity structures, political opportunity structures, organizational resources and ideological frames of the given problems. A combination of these factors has to some extent led to efforts which are becoming visible in the last few years in Greece in the form of AAFNs. These networks-initiatives encompass the abandonment of the ecologically destructive economic system and the enactment of a more sustainable form of production (Forno, 2013).

Therefore, AAFNs are re-embedding production and consumption into new social relations and dis-embedding them from dependence on large economic state actors and institutions in the current industrial agro-food system thus avoiding the risk of withdrawing and adding processes to rural ecosystems (Goodman and Goodman, 2009). On the other hand, they are attempting to change an economic system, increasingly perceived as unfair and ecologically disruptive, by building an alternative in the cracks of the former, based on greater mutual solidarity between individuals and more sustainable connections with the environment. The most representative and viable AAFNs in Greece, although small in number, are organic farmers markets "Agroname.com" "Gaea" and "Yni Pirouni" networks (Petropoulou, 2016).

Interest in the topic of the sustainability ${ }^{9}$ of farming involved in the above mentioned AAFNs is justified by the fact that they deal with some of the most topical issues found

8 The methodological tools adopted by Greek AAFNs are partially derived from an EU funded project (LIVEWHAT http://www.livewhat.unige.ch), for more details see Petropoulou, 2016.

9 In this paper, I refer to the concept of sustainability defined by the World Commission on Environment and Development (1987), which takes into account the interrelation between social, environmental and economic issues. The short supply chain touches each of these three aspects of sustainability since it can "re-connect" agriculture to consumers (Curry, 2002) either socially, through dialogue and the sharing of information between the parties involved, or economically and environmentally, where agricultural resources are managed with the view of obtaining profits and maintaining public goods, respectively. 
within the debate on food and, particularly, the food paradox question; the problem regarding the relationship between global change, availability of natural resources and farm production; the economic and social conflicts that emerge between various players within food chains; and the issue of interaction between cities, as places of consumption, and the countryside, as places of production. The main ideology of Greek AAFNs is the refusal of food chain players to accept and adopt the defining elements to traditional supply chains, such as excessive productivity leading to ecological marginalization, standardization and industrial organization (Higgins et al., 2008), placing instead a greater emphasis on other aspects, such as ecosystem preservation, food quality, origin and the 'naturality' of agro-food production (Renting et al., 2012).

From an environmental point of view, Greek farmers that adopt forms of AAFNs tend to implement more sustainable production methods, which in turn have a positive impact on biodiversity, the landscape and the natural resources of the territory (Gilg and Battershill, 2000; Holloway, 2006). The necessity of diversifying production to meet consumer demand for variety has pushed farmers towards the most diverse farming practices, with the result being that they do not specialize in one or two products, but instead offer a wide range of different goods. This often leads to rediscovering traditional vegetables, ancient fruit cultivations and dairy products made from the milk of indigenous breeds. The reorganization of production systems can also cover the decision to introduce production methods with lower environmental impact, such as organic farming or integrated agriculture (Little et al., 2010).

Healthwise, the four types of Greek AAFNs have increased knowledge and concern about food amongst consumers and this has led to the adoption of healthier diets. The potential for healthier food in AAFNs is created by both formal measures (e.g. a broad variety of fresh food, especially fruit and vegetables, no use of chemical inputs) and informal measures (communication to consumers), but cannot always be fully reached due to trade-offs with other characteristics.

Looking at social reasons, local farmers markets and internet platforms, such as the "Agroname.com" network, generate a net profit in terms of employment (DuPuis and Goodman, 2005). AAFNs present young farmers with the opportunity of developing their activity, while pensioners can earn additional income by taking up farming (Karner, 2010). In addition, the expansion of sales-related initiatives may require employing workers outside the family to cover the increased need for labor, creating further employment opportunities for people living in rural areas, and in this way promoting a virtuous circle that benefits everyone in the territory (O'Neill, 2014).

Local markets, where relationships are easily made on a personal level and are linked to this shared space (Hinrichs, 2000; Ilberry and Maye, 2005), provide the ideal opportunity for exchanging information and opinions about production techniques, the specific characteristics of a product and more in general countryside knowledge (Renting et al., 2003). Following these considerations, one could even interpret the spreading of new supply chain forms as a political tool, used to back the will of certain public administrations of retaining agriculture and farming in the areas surrounding towns instead 
of transforming previously farmed land into urban areas (Aubry et al., 2008) without withdrawing or adding to the rural environment.

Economically, farmers taking part in AAFNs such as "Gaea" and "Yni Pirouni" can make a significant profit. They have a direct input on price, which can be determined in a totally autonomous way (Cicatiello and Franco, 2008). This allows farmers to regain control over decisions about what to produce (Hinrichs, 2000) and so escape from the vicious circle typical of traditional markets. This also means that they can avoid the so-called squeeze on agriculture (van der Ploeg, 2006), namely, the situation whereby farmers are pressed on the one side by their suppliers and on the other by the wholesalers to whom they sell their products, so that they gradually lose their decision-making autonomy. Producers taking part in AAFNs have enhanced entrepreneurial skills in aspects such as customer relationships, marketing and business self-confidence (Ilberry and Maye, 2005). A further economic advantage is that of immediate financial gain (Aubry and Kebir, 2013). Through AAFNs, farmers can sell their products during periods of the year when offer exceeds demand (Renting et al., 2012), while at the same time continuing to use traditional marketing channels. In this way, placing products without creating a surplus allows farmers to sell their produce for more than they would have obtained from a wholesaler, while consumers can pay less than regular retail prices (Karner, 2010).

Finally, Greek AAFNs can act as a driver of positive change regarding ecological marginalization as they can be perceived as a method to increase sustainability, trust, equality and growth in agricultural, food, business, social, health and rural policy areas without threatening local ecosystems. In line with the above, what has been argued so far is that the Greek AAFNs try to resist the expansion of global capitalism in rural areas by engaging in the production of alternative and contentious socio-ecological configurations. Forno and Graziano (2014) stress that the common denominator of AAFNs is their criticism of the productivism of modern farms and the desire to re-articulate consumption and production on a smaller scale. Also, the above presented networks-initiatives support the re-localization of economic activities to be re-embedded in social relations, characteristics and objectives that sound familiar to de-growth supporters (D'Alisa et al., 2014).

\section{CONCLUSIONS}

Rural populations, and particularly farmers whose economy and livelihood are dependent on the local ecosystems, are directly impacted by ecological marginalization processes. Ecological marginalization entails the take-over of local natural resources by powerful private or state and international actors such as the EU by gradually disorganizing the rural ecosystem through withdrawals and additions. Chemical agriculture, single crops, intensive livestock husbandry and the sprawl of urbanization constitute typical activities by those actors, leading rural people to the loss of their resource base and to the generation of socio-economic and public health risks. Ecological marginali- 
zation which has established itself in the rural areas of Greece and elsewhere in the last several decades has its roots in top-down decision making influenced by core centers of power leading thus to non-sustainable activities at the local level.

Nonetheless, ecological marginalization creates the necessary preconditions that may lead to environment-linked forms and networks of sustainable production and consumption patterns particularly in times of crisis. Alternative Agro-Food Networks (AAFNs) in Greece are mainly concerned with re-grounding agriculture on nature and decent work, delinking agriculture from dependency on market dynamics and on financial and industrial capital, re-introducing local knowledge, implementing a new generation of skill-oriented technologies, and experimenting with new forms of local cooperation, etc. (van Ploeg, 2008). These notions are fundamental in conceptualizing a viable alternative to "industrial-entrepreneurial" and "corporate agriculture". Within this framework, AAFNs become a more far reaching notion than just direct and trusting relations between farmers and consumers: this includes de-commoditized relations to the environment and to rural and urban territories. It also means supporting alternative food supply schemes that demand local democracy and defending local ecosystems against large infrastructures or privatization of rural public goods therefore promoting a new rural development paradigm.

Finally, for the advancing of scientific knowledge, it is important to map the redundancy of the various views on current alternative food supply schemes and practices in order to predict their stability, predictability and integration; in short, to unveil their connecting structure and making these initiatives or collective actions more reliable. To accomplish this, new fresh social solutions and methods such as social innovation, although limited in number, can adequately respond to the current multiple economic, social and environmental crises ${ }^{10}$. This kind of method (i.e. social innovation and / or network analysis) could be considered as an innovative way to make people more aware and possibly more engaged in sustainability issues (BEPA, 2014).

\section{REFERENCES}

Andrersson, E. and Lundqvist, P. (2014). Gendered agricultural space and safety: Towards embodied, situated knowledge. Journal of Agromedicine, 19 (3): 303-315. Aubry, D. and Kebir, L. (2013). Shortening food supply chains: A means for maintaining agriculture close to urban areas? The case of the French metropolitan area of Paris. Food Policy, 41: 85-93.

Benoit, G. and Comeau, A. (2005). A sustainable future for the Mediterranean: the Blue Plan's environment and development outlook. London: Earthscan.

10 For more details see URL: http://livewhat.unige.ch/wp-content/uploads/2014/07Analysis-of-Web-Accessible-Networks-Organisations-and-Groups.pdf 
Beopoulos, N. and Skuras, N. (1997). Agriculture and the Greek rural environment. Sociologia Ruralis, 37(2): 255-269.

Beopoulos, N. and Vlachos, G. (2004). Policy measures in an environmentally sensitive area specialised in sheep breeding. The case of north-western Lesvos. In: Wilson G. A. and Juntti, M. (eds.), Unravelling Desertification: Policies and Actor Networks in Southern Europe (pp. 157-178). Wageningen: Wageningen Academic Publishers.

Beaufoy, G., Baldock, D., Clark, J. (1994). The nature of farming: low intensity farming systems in nine European countries. London: Institute for European Environmental Policy.

Berkes, F. (2008). Sacred Ecology, New York: Routledge.

Bourdaras, D. (2007). The EU Agricultural policy in the F\&V sector and the Greek implementation. Athens: Ministry of Greek Agriculture.

Blondel, J. (2006). The 'design' of Mediterranean landscapes: A millennial story of humans and ecological systems during the historic period. Human Ecology, 34(5): 713-729.

Briassoulis, H. (2004). The institutional complexity of environmental policy and planning problems: The example of Mediterranean desertification. Journal of Environmental Planning and Management, 47(1): 115-135.

Bureau of European Policy Advisors (BEPA). (2014). Social innovation. A decade of changes. A BEPA report. URL: http://espas.eu/orbis/sites/default/files/generated/ document/en/social_innovation_decade_of_changes.pdf

Caraveli, H. (2000). A comparative analysis on intensification and extensification in Mediterranean agriculture: dilemmas for LFAs policy. Journal of Rural Studies, 16: 231-242.

Castells, M., Caraçao J., Cardoso G. (2012). Aftermath. The culture of economic crises. Oxford: Oxford University Press.

Cosyns, H., Van Damme, P., De Wulf, R., Degrande, A. (2014). Can rural development projects generate social capital? A case study of Ricinodendron heudelotii kernel marketing in Cameroon. Small-scale Forestry, 13 (2): 163-182.

Demos, K., Sazaki, E., Jelastopulu, E., Charokopos, N., Ellul, J., Leotsinidis, M. (2013). Does farming have an effect on health status? A comparison study in West Greece. International Journal of Environmental Research and Public Health, 10: 776-792.

D’Alisa, G., Demaria, F., Cattaneo, C. (2013). Civil and Uncivil Actors for a Degrowth Society. Journal of Civil Society, 9(2): 212-24.

D’Alisa, G., Demaria, F., Kallis, G. (2014). Degrowth. A vocabulary for a new era. London: Routdledge.

DuPuis, M. and Goodman, D. (2005). Should we go 'home' to eat? Toward a Reflective Politics of Localism. Journal of Rural Studies, 21: 359-371.

Ethniki Statistiki Ypiresia Elladas [National Statistical Service of Greece] (ESYE). (1964). Apotelesmata tis apografis plithismou katoikion tis 19 Martiou 1961 [The population-housing census results of 19th March 1961]. Athens: ESYE. 
Ethniki Statistiki Ypiresia Elladas [National Statistical Service of Greece] (ESYE). (1972a). Apotelesmata tis apografis plithismoukatoikion tis 14 Martiou 1971 [The population-housing census results of 14th March 1971]. Athens: ESYE.

Ethniki Statistiki Ypiresia Elladas [National Statistical Service of Greece] (ESYE). (1972b). Plithismos tis Ellados kata tin apografin tis 14 Martiou 1971 [The population of Greece of the 14th March 1971 census]. Athens: ESYE.

Ethniki Statistiki Ypiresia Elladas [National Statistical Service of Greece] (ESYE). (1991). Apotelesmata tis apografis plithismoukatoikion tis 5 Apriliou 1981 [The population-housing census results of 5th April 1981]. Athens: ESYE.

Ethniki Statistiki Ypiresia Elladas [National Statistical Service of Greece] (ESYE). (1994). Pragmatikos plithismos tis Ellados kata tin apografi tis 17 Martiou 1991 [Real population of Greece in the census of 17th March 1991]. Athens: ESYE.

Ethniki Statistiki Ypiresia Elladas [National Statistical Service of Greece] (ESYE). (2004). Monimos plithismos tis Ellados, Apografi 2001 [Permanent population of Greece, census 2001]. Athens: ESYE.

Fisher, R. (2013). "A gentleman's handshake": the role of social capital and trust in transforming information into usable knowledge. Journal of Rural Studies, 31: 13-22.

Forno, F. (2013). Co-operative movement. In: Snow, D. A., della Porta, D., Klandermans, B., McAdam, D. (eds.), Blackwell Encyclopedia of Social and Political Movements (pp. 278-280). Oxford, Blackwell publishing.

Forno, F. and Graziano P. (2014). Sustainable community movement organizations. Journal of Consumer Culture, 14(2): 139-157.

Galanis, D. and Karagiannis, N. (2000). How Argolida was filled with nitrates. Vima on line. URL: http://www.tovima.gr/relatedarticles/article/?aid=118482 (July 19, 2016).

Gilg, A. W. and Battershill, M. (2000). To what extent can direct selling of farm produce offer a more environmentally friendly type of farming? Some evidence from France. Journal of Environmental Management, 60: 195-214.

Grasseni, C., Forno F., Signori, S. (2015). Beyond Alternative Food Networks: In-sights from Italy's Solidarity Purchase Groups and US Community Economies, In: Utting, P. (ed.), Social and Solidarity Economy: Beyond the Fringe? (pp. 185-201). London: Zed Books.

Gomez-Baggethun, E., Mingorria, S., Reyes-Garcia, V., Calvet, L., Montes, C. (2010). Traditional ecological knowledge trends in the transition to a market economy: Empirical study in the Donana Natural Areas. Conservation Biology, 24(3): 721-729.

Goodman, D. and Goodman, M. (2009). Food networks, alternative. In: Kitchin, R. and Thrift, N. (eds.), International Encyclopedia of Human Geography (pp. 208221). Amsterdam: Elsevier.

Higgins, V, Dibden, J., Cocklin, C. (2008). Building alternative agri-food networks: Certification, embeddedness and agri-environmental governance. Journal of Rural Studies, 24(1): 15-27.

Hinrichs, C. (2000). Embeddedness and local food markets: notes on two types of direct agricultural markets. Journal of Rural Studies, 16: 295-303. 
Holloway, L., Cox, R., Venn, L., Kneafsey, M., Dowler, E., Tuomainen, H. (2006). Managing sustainable farm landscape through 'alternative' food networks: a case study from Italy. Geographical Journal, 172(3): 219-229.

Ilbery, B. and Maye, D. (2005). Alternative (shorter) food supply chains and specialist livestock products in the Scottish and English border. Environment and Planning A, 37(5): 823-844.

International Labour Organization (ILO) (2011). Safety and Health in Agriculture (ILO code of practice). Geneva: ILO.

Kallis, G., Martinez-Alier J., Norgaard, R. (2009). Paper assets, real debts: An ecological economic exploration of the global economic crisis. Critical Perspectives on International Business, 5(1-2): 14-25.

Karner, S. (ed.), (2010). Local Food Systems in Europe. Case studies from five countries and what they imply for policy and practice (FAAN report). Graz: IFZ.

Kizos, T., Vasdeki, M., Chatzikiriakou C., Dimitriou, D. (2011). 'For my children': Different functions of the agricultural landscape and attitudes of farmers on different areas of Greece towards small scale landscape change. Geografisk Tidsskrift-Danish Journal of Geography, 111(2): 117-130.

Kizos, T. and Vlachos, G. (2012). The evolution of the agricultural landscape. In: Papayiannis, T. and Howard, P. (eds.), Reclaiming the Greek landscape (pp. 133-143). Athens: MED-INA.

Kousis, M. (1997). The environmental movement revisited: the challenges and the challenged in an era of ecological marginalization and sustainable development. Paper presented at the ISA's RC 24 Conference, Sociological theory and the environment. Woudschoten, The Netherlands. March 20-23.

Kousis, M. (1998). Ecological marginalization in rural areas: actors, impacts, responses. Sociologia Ruralis, 38(1): 86-108.

Lekakis, J. N. and Kousis, M. (2013). Economic crisis, Troika and the environment in Greece. South European Society and Politics, 18(3): 305-331.

Liodakis, G. (1997). Technological change in agriculture: a Marxist critique. Sociologia Ruralis, 37(1): 61-68.

Little, R., Maye, D., Ilbery, B. (2010). Collective purchase: Moving local and organic foods beyond the niche market. Environment and Planning A, 42(8): 1797-1813.

Lorent, H., Sonnenschein, R., Tsiourlis, G. M., Hostert, P., Lambin, E. (2009). Livestock subsidies and rangeland degradation in central Crete. Ecology and Society 14(2): 41. URL: http://www.ecologyandsociety.org/vol14/iss2/art41/ (July 19, 2016).

Louloudis, L. and Beopoulos, N. (2002). Broadening the sectoral perspective on agricultural policy in Greece. In: Brouwer, F. and van der Straaten, J. (eds), Nature and agriculture in the European Union. New perspectives on policies that shape the European countryside (pp. 182-207). Cheltenham: Edward Elgar Publishing.

Maraveyias, N. and Mermigkas, G. (2002). The European integration of Greek agriculture: twenty years after the accession to the EU. In: Ioakimidis, P. (ed.), Greece in the European Union: the new role and the new agenda. Athens: Ministry of Press and Mass Media. 
Martin, P. (2016). Ecological restoration of rural landscapes: stewardship, governance and fairness. Restoration Ecology, 24(5): 680-685.

Millington, A. C. (1991). Land use transformation and environmental impacts of EC agricultural policy and rural development: Messinia, Greece. In: Jones, G. and Robinson, G. (eds.), Land use change and the environment in the European Community (pp. 107-121). London: Biogeography Research Group and Rural Geography Study Group of the Institute of British Geographers.

Murray, E. K. and Skuras, D. G. (1990). Land fragmentation and consolidation policies in Greek agriculture. Geography, 75(1): 73-76.

O'Neill, K. (2014). Localized food systems - what role does place play? Regional Studies, Regional Science, 1(1): 82-87.

Papadopoulos, D. (1999). In the shadow of the public transnational capital: a scenario about state agronomists' downgrading role in rural development (1981-1994). In: Kasssimis, C. and Louloudis, L. (eds.), Rural space: the Greek rural society at the end of the 20 th century (pp. 237-256). Athens: Plehron.

Paraskevopoulos, C. J. (2007). Social capital and public policy in Greece. GreeSE Paper No. 9, Hellenic Observatory Papers on Greece and Southeast Europe. London: The Hellenic Observatory, London School of Economics and Political Science.

Parayil, G. (1992). The Green Revolution in India: A Case Study of Technological Change. Technology and Culture, 33(4): 738-739.

Petanidou, T., Kizos, T., Soulakellis, N. (2008). Socioeconomic Dimensions of Changes in the Agricultural Landscape of the Mediterranean Basin: A Case Study of the Abandonment of Cultivation Terraces on Nisyros Island, Greece. Environmental Management, 41: 250-266.

Petropoulou, E. A. (2007). Indigenous resource management and environmental degradation: southern Greece. Management of Environmental Quality: An International Journal, 18(2): 152-165.

Petropoulou, E. A. (2014). Permanent crisis in a lowland community of southern Crete, In: Zambarloukou, S. and Kousis, M (eds.), Social aspects of the crisis in Greece (pp. 171-198). Athens: PEDIO.

Petropoulou, E. A. (2016). The role of short food supply chains in Greece - What opportunities for sustainable, just and democratic food systems at times of crisis? Sociology and Anthropology, 4(5): 337-346.

Petropoulou, E. A. and Petousi, V. (2016). Agriculture and women's health: Investigating the relationship, findings and recommendations on the basis of international literature and research. In: Koniordos, S. M. (ed.), The Greek society at the crossroads of crisis, six years after (pp. 546-556). Athens: Greek Sociological Association.

Petsikou, V. (2001). Nitrate pollution in surface and underground water: the implementation of directive 91/676/EEC in Greece. (M.A. dissertation). Mytilini: University of Aegean, Department of Environment.

Pezaros, P. D. (2012). The Common Agricultural Policy: progress and prospects. In: Dalis, S. (ed.), From the accession to the crisis, Greece and European Union: 19812011 (pp. 192-213). Athens: Papazisis. 
Primdahl, J. (2010). Globalisation and the local agricultural landscape: current change patterns and public policy interventions. In: Primdahl, J. and Swaffield, S. (eds.), Globalisation and Agricultural Landscapes: Change Patterns and Policy Trends in Developed Countries (pp. 149-167). Cambridge: Cambridge University Press.

Renting, H., Marden, T. and Banks, J. (2003). Understanding alternative food networks: exploring the role of short food supply chains in rural development. Environment and Planning, 35(3): 393-411.

Renting, H., Shermer, M. and Rossi, A. (2012). Civic Food Networks. International Journal of Sociology of Agriculture and Food, 19(3): 289-307.

Schnaiberg, A. (1980). The Environment: From Surplus to Scarcity. New York: Oxford University Press.

Sotiropoulos, D. (2014). The dual face of Ianos: civil society in Greece before and after the beginning of the economic crisis. Greek Political Science Review, 42: 11-35.

Symeonakis, E., Caccetta, P., Koukoulas, S., Furby, S., Karathanasis, N. (2012). Multitemporal landcover classification and change analysis with conditional probability networks: The case of Lesvos Island (Greece). International Journal of Remote Sensing, 33(13): 4075-4093.

van der Ploeg, J. D. (2006). Agricultural production in crisis. In: Cloke, P., Marsden, T., Mooney, P. (eds.), Handbook of rural studies (pp. 258-278). Sage Publications: London.

Vlachos, G. (2011). The urbanization of rural land. In: Efthimiopoulos, E. and Modinos, M. (eds.), Where is the future of agriculture heading (pp. 133-149). Athens: Livanis editions.

World Commission on Environment and Development (WCED) (1987). Our Common Future: Report of the World Commission on Environment and Development. Oxford: Oxford University Press. 


\title{
EKOLOŠKA MARGINALIZACIJA I LOKALNI ODGOVORI U RURALNOJ GRČKOJ
}

\author{
Eugenia A. Petropoulou
}

\begin{abstract}
Sažetak
Uvjeti pod kojima žive stanovnici ruralnih područja, načini na koje iskorištavaju prirodne resurse i izgledi koje imaju za održanje u budućnosti uvijek su barem dijelom odraz politika nacionalnih vlada, politika ekonomskog i sektorskog razvoja Europske unije, te razlicitih procesa poput globalizacijskih. U radu se kroz ideju ekološke marginalizacije žele prikazati posljedice jačanja sprege izmedu politike Europske unije, grčke vlade i domaćih grčkih proizvođača kroz razvoj intenzivne poljoprivrede. Budući da su mnogi prirodni resursi - tlo, voda i bioraznolikost - već postali dio proizvodnih sustava industrijske poljoprivrede, u radu se ta proizvodnja analizira kako bi se pokazalo da politike grčke vlade, pristup Europskoj zajednici 1981. godine, te načini lokalnog iskoristavanja tla najviše doprinose mogućim posljedicama za budući poljoprivredni razvoj. Iako postoje varijacije u učincima intenzivne poljoprivrede s obzirom na regije, pa neke ruralne regije imaju koristi od njenog razvoja, analiza upućuje na zaključak da ruralno stanovništvo i ruralne zajednice te gradani periurbanih područja nose najveći teret proizvodnog sustava industrijske poljoprivrede. Jedan od glavnih razloga pronalazimo u postojećim „spregama“ unutar intenzivne industrijske poljoprivrede koje doprinose jačanju pritiska na ekološki integritet ruralnih područja, što pak dovodi do uništavanja okoliša i marginalizacije ili napustanja poljoprivrede. Na kraju, u radu se analiziraju slučajevi Alternativnih agro-prehrambenih mreža (engl. Alternative Agro-Food Networks - AAFN) u Grčkoj kako bi se ukazalo na načine na koje je moguće razvijati socio-ekonomsku održivost $i$ zdravlje lokalnih proizvodača i potrošača kao alternativu postojećem sustavu intenzivne agro-industrijske poljoprivrede koja dovodi do ekološke marginalizacije.
\end{abstract}

Ključne riječi: Alternative Agro-Food Networks, ekološka marginalizacija, Europska unija, Grčka, ruralna područja

\section{ÖKOLOGISCHE MARGINALISIERUNG UND REAKTION DER EINHEIMISCHEN IM LÄNDLICHEN GRIECHENLAND}

\author{
Eugenia A. Petropoulou
}

\section{Zusammenfassung}

Die Lebensverhältnisse der Einwohner in ländlichen Gebieten, die Art und Weise, wie sie die Naturressourcen nutzen und die Chancen für eine zukünftige Erhaltung, die sie haben, sind immer, wenigstens teilweise, ein Spiegelbild der Politiken der nationalen Regierungen, der Politik der Wirtschafts- und Sektorentwicklung der Europäischen Union, sowie jenes verschiedener Prozesse, wie z.B. derjenigen der Globalisierung. Aus der Perspektive der ökologischen Marginalisierung werden in der vorliegenden Arbeit die Auswirkungen der Stärkung des Bündnisses der EU-Politik, der griechischen Regierung und der einheimischen griechischen Produzenten auf die Entwicklung der intensiven Landwirtschaft dargestellt. Da viele Naturressourcen - der Boden, das Wasser und die Biodiversität - schon zu einem Bestandteil der Produktionssysteme der industriellen Landwirtschaft geworden sind, wird in der Arbeit diese Produktion analysiert, damit gezeigt wird, dass die Politik der griechischen Regierung, der EU-Beitritt im Jahr 1981, sowie die Methoden der lokalen Bodennutzung die Entwicklung der Landwirtschaft am meisten beeinträchtigen. Obwohl die Auswirkungen der intensiven Landwirtschaft in verschiedenen Regionen variieren und einige ländliche Regionen von ihrer Entwicklung Nutzen haben, weist die Analyse auf den Schluss hin, dass ländliche Bevölkerung, Gemeinden und Bürger aus periurbanen Gebieten die größte Last des Produktionssystems der industriellen Landwirtschaft tragen. Einer der Hauptgründe dafür liegt in den bestehenden „Bündnissen“ innerhalb der intensiven industriellen Landwirtschaft, die dazu beitragen, dass der Druck 
auf die ökologische Integrität der ländlichen Gebiete stärker wird, was zur Umweltzerstörung und Marginalisierung und Aufgabe der Landwirtschaft führt. Zum Schluss werden in der Arbeit Fälle von Alternativen Agro-Nahrungsnetzen (Alternative Agro-Food Networks - AAFN) in Griechenland analysiert, damit darauf hingewiesen werden kann, wie man die sozio-ökonomische Nachhaltigkeit und die Gesundheit lokaler Produzenten und Verbraucher entwickeln kann als Alternative für das bestehende System der intensiven agro- industriellen Landwirtschaft, die zu einer ökologischen Marginalisierung führt.

Schlüsselwörter: Alternative Agro-Food Networks, ökologische Marginalisierung, Europäische Union, Griechenland, ländliche Gebiete 